\title{
PENGARUH PENGHARGAAN (REWARD), BUDAYA KERJA DAN HARAPAN BERKEMBANG TERHADAP KINERJA ANGGOTA KEPOLISIAN DI DIREKTORAT RESERSE KRIMINAL KHUSUS (DITRESKRIMSUS) POLDA KALIMANTAN SELATAN
}

\author{
Sheren Septiana \\ Sekolah Tinggi Ilmu Ekonomi Pancasetia Banjarmasin \\ Jl. Ahmad Yani Km. 5.5 Banjarmasin \\ septiana.sheren@gmail.com
}

\begin{abstract}
Abstrak: Sheren Septiana, Npm. 1811.32202.4740, Pengaruh Penghargaan (Reward), Budaya Kerja Dan Harapan Berkembang Terhadap Kinerja Anggota Kepolisian Di Direktorat Reserse Kriminal Khusus (Ditreskrimsus) Polda Kalimantan Selatan, Dibawah Bimbingan Arief Noviarakhman Dan Melania, 2020. Tujuan yang ingin dicapai dalam penelitian ini adalah untuk mengetahui dan menganalisis pengaruh penghargaan (reward) terhadap kinerja anggota kepolisian, untuk mengetahui dan menganalisis pengaruh budaya kerja terhadap kinerja anggota kepolisian dan untuk mengetahui dan menganalisis pengaruh harapan berkembang terhadap kinerja anggota kepolisian di Direktorat Reserse Kriminal Khusus (Ditreskrimsus) Polda Kalimantan Selatan.Populasi dan sampel dalam penelitian ini adalah 36 orang anggota kepolisian Ditreskrimsus Polda Kalimantan Selatan. Jenis datan penelitian asosiatif dengan paradigma kuantitatif, menggunakan perhitungan statistik dengan program SPSS 17 dengan analisis regresi berganda. Hasil penelitian pertama diketahui bahwa variabel penghargaan (reward) berpengaruh signifikan terhadap kinerja anggota kepolisian di Direktorat Reserse Kriminal Khusus (Ditreskrimsus) Polda Kalimantan Selatan. Hasil penelitian kedua diketahui bahwa variabel budaya kerja berpengaruh signifikan terhadap kinerja anggota kepolisian di Direktorat Reserse Kriminal Khusus (Ditreskrimsus) Polda Kalimantan Selatan. Hasil penelitian ketiga diketahui bahwa variabel harapan berkembang berpengaruh signifikan terhadap kinerja anggota kepolisian di Direktorat Reserse Kriminal Khusus (Ditreskrimsus) Polda Kalimantan Selatan.
\end{abstract}

Kata Kunci: Penghargaan, Budaya Kerja, Harapan Berkembang dan Kinerja 


\section{BAB I \\ PENDAHULUAN}

\subsection{Latar Belakang Masalah}

Pengembangan sumber daya manusia adalah untuk memperbaiki efektivitas dari kinerja dalam mencapai hasil yang ditetapkan.Sehubungan tersebut dalam rangka meningkatkan kinerja pegawai faktor yang perlu diperhatikan adalah masalah penghargaan (reward). Penghargaan sangat penting bagi organisasi/instansi karena mencerminkan upaya organisasi untuk mempertahankan sumber daya manusia sebagai komponen utama dan merupakan biaya yang penting, disamping pertimbangan tersebut penghargaan juga merupakan salah satu aspek yang berarti bagi pegawai, karena individu atau pegawai besarnya penghargaan mencerminkan bentuk perhatian dari instansi terhadap prestasi yang dihasilkan pegawai. Pemberian penghargaan bisa berbentuk materi maupun non materi, bentuk materi bisa berbentuk bonus, insentif maupun tanda penghargaan, sedangkan non materi bisa berbentuk ucapan pujian maupun penghargaan dalam bentuk mendali. Menurut Nitisemito (2006:87) menjelaskan penghargaan (reward) merupakan balas jasa yang diberikan oleh perusahaan/organisasi kepada para pegawai yang dapat dinilai dengan uang dan mempunyai kecenderungan diberikan secara tetap. Penghargaan berarti semua bentuk penggajian atau ganjaran kepada pegawai dan timbul karena pegawai mereka dapat bekerja secara baik. Penghargaan tersebut bisa berbentuk uang secara langsung (uang, gaji, insentif, bonus) dan dapat pula berbentuk pembayaran tidak langsung (asuransi dan liburan). Dengan diberikannya penghargaan tersebut akan dapat meningkatkan motivasi dan kinerja pegawai. Titik awal untuk mendukung pelaksanaan reformasi birokrasi di bidang kepegawaian/aparatur negara pada pemerintah di daerah, harus diawali dan dibenahi dengan perbaikan budaya kerja. Menurut KEP MENPAN No 04/199 menjelaskan tentang budaya kerja adalah merupakan sikap hidup yang didasari oleh pandangan hidup sebagai nilai-nilai yang menjadi sifat, kebiasaan dan kekuatan pendorong yang membudaya dalam kehidupan suatu kelompok yang kemudian tercermin dalam perilaku, kepercayaan, cita-cita, pendapat dan tindakan yang terwujud sebagai "kerja" atau "bekerja". Terkait dengan hal tersebut aparatur negara terdapat stigma bahwa selama ini masih terdapat adanya aparatur kurang profesional dalam bekerja, hal lain yang juga kerap menjadi opini publik. Masih terlihat perilaku pegawai yang kurang optimal dalam bekerja karena tidak sesuai dengan tupoksi, selain itu kerap kali perilaku yang ada di dalam diri aparatur negara tersebut membuat karakter diri yang kurang bertanggung jawab dan kurang sesuai harapan dalam bekerja, awal dari munculnya kebiasaan tersebut kemudian membudaya dilingkungan kerja yang berdampak terdapat kinerja menjadi kurang optimal. Faktor lain yang juga dapat mempengaruhi kinerja seseorang adalah adanya harapan berkembang. Harapan adalah bentuk dasar dari kepercayaan akan sesuatu yang diinginkan akan didapatkan atau suatu kejadian akan berbuah kebaikan di waktu yang akan datang (Moenir, 2010:210). Harapan berkembang dalam hal ini adalah adanya keinginan dan kesempatan untuk berkembang dalam karier atau pekerjaan, dengan adanya harapan tersebut akan mendorong seseorang untuk dapat bekerja menjadi lebih baik, namun apabila seseorang bekerja tidak mempunyai harapan atau keinginan yang jelas dalam bekerja, maka hal ini akan membuat seseorang men jadi tidak mempunyai tujuan, sehingga dalam bekerja pun tidak akan pernah serius dan fokus dalam menjalankannya. Terkait dengan ketiga variabel tersebut, baik permasalahan penghargaan (reward), budaya kerja maupun masalah harapan bekermbang, hal ini pun kerap kali menjadi isu dilingkungan kepolisian khususnya di Direktorat Reserse Kriminal Khusus (Ditreskrimsus) Polda Kalimantan Selatan. Direktorat Reserse Kriminal Khusus (Ditreskrimsus) Polda Kalimantan Selatan adalah sebuah institusi kepolisian merupakan unsur pelaksana 
tugas pokok yang berada dibawah Kapolda

Kalimantan Selatan yang bertugas menyelenggarakan penyelidikan dan penyidikan tindakan pidana khusus, koordinasi, pengawasan, operasional dan administrasi penyidikan PPNS sesuai dengan ketentuan peraturan perundangundangan. Direktorat Reserse Kriminal Khusus Polda Kalimantan Selatan dalam melaksanakan tugas menyelenggarakan fungsi, yaitu penyelidikan dan penyidikan tindak pindana khusus, antara lain tindak pidana ekonomi, korupsi, dan tidak pidana tertentu di daerah hukum Polda Kalimantan Selatan, penganalisisan kasus beserta penganannya serta mepelajari dan mengkaji efektivitas pelaksana tugas, pembinaan teknis, koordinasi, dan pengawasan operasional serta administrasi penyidikan oleh PPNS, pelaksanaan pengawasan penyedikan tindak pidana khusus di lingkungan Polda dan pengumpulan dan pengolahan data serta menyajikan informasi dan dokumentasi program kegiatan Deskrimsus. Terkait dengan permasalahan reward di Direktorat Reserse Kriminal Khusus (Ditreskrimsus) Polda Kalimantan Selatan selama ini terkesan kurang perhatian yang mana ada beberapa anggota kepolisian yang dapat mengungkap kasus sulit dan menonjol serta prioritas untuk diungkap berhasil diselesaikan dengan baik, namun hal tersebut belum mampu menjadi tolak ukur pihak yang berkompeten di instansi kepolisian untuk memberikan reward kepada prestasi kerja dari anggotanya tersebut. Dilain pihak di intitusi Ditreskrimsus Polda Kalimantan Selatan masih terbentuk budaya-budaya kerja yang ada dan hal tersebut kerap kali mengganggu dan menghambat jalannya kinerja anggota dan organisasi, sitigma budaya tersebut seperti masih adanya budaya kurang disiplin dan kurang profesional dalam bekerja. Selain dari kedua permasalahan tersebut adapula permasalahan internal yang kerap kali dihadapi oleh pihak Ditreskrimsus Polda Kalimantan Selatan adanya kinginan harapan berkembang dari segenap anggota polisi sangatlah kuat dalam karier dan jabatan mereka, selama ini mereka beranggapan untuk mencapai tingkat karier dan jabatan sangatlah sulit untuk dicapai dilingkungan Ditreskrimsus Polda Kalimantan Selatan, sehingga akibat permasalahan ini berdampak kepada aktivitas kerja anggota polisi menjadi kurang optimal dalam bekerja, karena harapan mereka sulit untuk dicapai sehingga secara umum mereka bekerja hanya menunaikan kewajiban saja namun tidak lebih dari itu dengan kata lain mereka bekerja seperti tanpa tujuan yang jelas, sehingga hal ini berdampak terhadap kegiatan kinerja anggota polisi selama ini. Sehubungan permasalahan yang telah dikemukanan tersebut, maka dalam penelitian ini penulis tertarik untuk melakukan penelitian dengan judul Pengaruh Penghargaan (Reward), Budaya Kerja dan Harapan Berkembang Terhadap Kinerja Anggota Kepolisian di Direktorat Reserse Kriminal Khusus (Ditreskrimsus) Polda Kalimantan Selatan.

\subsection{Rumusan Masalah}

Berdasarkan latar belakang yang telah penulis kemukakan tersebut, maka yang menjadi erumusan masalah dalam peneltian ini adalah sebagai berikut:

1. Apakah penghargaan (reward) berpengaruh signifikan terhadap kinerja anggota kepolisian di Direktorat Reserse Kriminal Khusus (Ditreskrimsus) Polda Kalimantan Selatan?

2. Apakah budaya kerja berpengaruh signifikan terhadap kinerja anggota kepolisian di Direktorat Reserse Kriminal Khusus (Ditreskrimsus) Polda Kalimantan Selatan?

3. Apakah harapan berkembang berpengaruh signifikan terhadap kinerja anggota kepolisian di Direktorat Reserse Kriminal Khusus (Ditreskrimsus) Polda Kalimantan Selatan?

\section{BAB II TINJAUAN PUSTAKA \\ 2.1. Landasan Teori \\ 2.1.1.Penghargaan (Reward) \\ Reward (penghargaan) kegiatan dimana organisasi menilai konstribusi pegawai dalam rangka mendistribusikan}


penghargaan moneter dan non moneter cukup langsung dan tidak langsung dalam kemampuan organisasi untuk membayar berdasarkan peraturan hukum (Schuler dan Jackson (2001:102). Hasibuan (2007:135) menjelaskan reward (penghargaan) adalah semua pendapatan yang berbentuk uang, barang langsung atau tidak langsung yang diterima pegawai sebagai imbalan atau jasa yang diberikan kepada perusahaan/ organisasi. Nitisemito (2006:87) menjelaskan reward (penghargaan) merupakan balas jasa yang diberikan oleh perusahaan/organisasi kepada para pegawai yang dapat dinilai dengan uang dan mempunyai kecenderungan diberikan secara tetap. Penghargaan berarti semua bentuk penggajian atau ganjaran kepada pegawai dan timbul karena pegawai mereka dapat bekerja secara baik. Penghargaan tersebut bisa berbentuk uang secara langsung (uang, gaji, insentif, bonus) dan dapat pula berbentuk pembayaran tidak langsung (asuransi dan liburan). Pemberian reward (penghargaan) mempunyai tujuan sebagai ikatan kerjasama, kepuasan kerja, pengadaan efektif, stabilitas pegawai dan disiplin (Hasibuan 2007:119).

1. Ikatan kerjasama.

2. Kepuasan kerja.

3. Pengadaan

4. Motivasi

5. Stabilitas pegawai

Menurut Swansburg, (2009:349) pemberian reward (penghargaan) dapat memberikan dampak positif terhadap perilaku pegawai, menimbulkan kepuasan kerja bagi pegawai, memberikan dampak positif terhadap kemampuan organisasi, mampu menghasilkanlah dirancang dan pancapaian tujuan yang tujuan yang telah dirancang dan mempertahankan lebih banyak pegawai yang mampu dalam bekerja untuk mencapai prestasi yang tinggi. Dalam peraturan pemerintah pemberian penghargaan bagi PNS dibentuk berbagai penghargaan, yaitu kenaikan pangkat, pengangkatan dalam jabatan, tanda Kehormatan Satyalencana Karya Satya, tunjangan Jabatan, Tunjangan Umum, Kenaikan Gaji Berkala, Gaji, Gaji ke 13, Cuti dan Pensiun
Sedangkan Halim dan Husnul (2012:111) menjelaskan alat-alat untuk memberikan penghargaan kerja adalah :

1) Pemberian dalam bentuk materiil insentif, yaitu alat motivasi yang diberikan dapat berupa uang dan atau barang yang mempunyai nilai pasar, yang dapat memberikan kebutuhan ekonomis, seperti : Kendaraan, rumah, dan lain-lain.

2) Non materiil insentif, yaitu alat penghargaan yang diberikan berupa barang /benda yang tidak ternilai, yaitu hanya memberikan kepuasan/kebanggaan rohani saja, seperti medali, piagam, bintang jasa, dan lain-lain

3) Kombinasi materiil dan nonmateriil insentif, yaitu alat motivasi yang diberikan untuk berupa materiil (uang dan barang) dan non materiil (medali dan piagam) yaitu pemenuhan ekonomis dan kepuasan.

\subsubsection{Budaya Kerja}

Budaya kerja dapat dikatakan sebagai seperangkat sistem yang nampak dalam nilai-nilai kerja, yang diperjuangkan dan diwujud-nyatakan menjadi satu tatanan manajemen yang berkualitas. Hal ini akan tercermin dari sikap yang menjadi perilaku, kepercayaan, cita-cita, pendapat dan tindakan yang diwujudkan di dalam bekerja. Menurut Wibowo (2011:65) budaya mengandung pengertian lingkup yang lebih luas. Bangsa-bangsa di dunia mempunyai budaya sendiri yang menjadi nasional. Dalam suatu Negara mungkin terdapat berbagai suku yang mempunyai budaya tersendiri, sebagai subkultur berdasarkan kesukuan atau kewilayahan. Budaya kerja adalah merupakan sikap hidup yang didasari oleh pandangan hidup sebagai nilai - nilai yang menjadi sifat, kebiasaan dan kekuatan pendorong yang membudaya dalam kehidupan suatu kelompok yang kemudian tercermin dalam perilaku, kepercayaan, cita - cita, pendapat dan tindakan yang terwujud sebagai "kerja" atau "bekerja". (KEP MENPAN No 04/1991). Menurut Eko (2013:128) mendefinisikan budaya sebagai asumsiasumsi dan pola-pola makna yang 
mendasar, yang dianggap sudah selayaknya dianut dan dimanifestasikan oleh semua pihak yang berpartisipasi dalam organisasi. Budaya diartikan juga sebagai seperangkat perilaku, perasaan dan kerangka psikologis yang terinternalisasi sangat mendalam dan dimiliki bersama oleh anggota organisasi. Sehingga untuk merubah sebuah budaya harus pula merubah paradigma orang yang telah melekat. Ndraha, (2013:76) menjelaskan budaya kerja terbentuk begitu satuan kerja atau organisasi itu berdiri. "being developed as they learn to cope with problems of external adaption and internal integration" artinya pembentukan budaya kerja terjadi tatkala lingkungan kerja atau organisasi belajar menghadapi masalah, baik yang menyangkut perubahanperubahan ekternal maupun internal yang menyangkut persatuan dan keutuhan organisasi. Robbins (1996) dalam Ndraha, (2013:77) menjelaskan bagaimana budaya kerja di bangun dan dipertahankan ditunjukkan dari filsafat pendiri atau pimpinannya. Selanjutnya budaya ini sangat dipengaruhi oleh kriteria yang digunakan dalam mempekerjakan pegawai. Tindakan pimpinan akan sangat berpengaruh terhadap perilaku yang dapat diterima, baik dan yang tidak. Bagaimana bentuk sosialisasi akan tergantung kesuksesan yang dicapai dalam menerapkan nilai-nilai dalam proses seleksi. Namun secara perlahan nilai-nilai tersebut dengan sendirinya akan terseleksi untuk melakukan penyesuaian terhadap perubahan yang pada akhirnya akan muncul budaya kerja yang diinginkan, meskipun perubahan budaya kerja memakan waktu lama dan mahal.

Budaya kuat adalah budaya kerja yang ideal. Dimana kekuatan budaya mampu mempengaruhi intensitas perilaku. Ada tiga ciri khas budaya kuat thickness,extent of sharing, dan clarity of ordering. Menurut Sathe, (1985) dalam Ndraha, (2013:122123). Sedangkan menurut Robbins " $A$ strong culture is characterized by the organization's core values being intensely held, clearly ordered, and widely shared". Semakin kuat budaya, semakin kuat pengaruhnya terhadap lingkungan dan perilaku manusia. (Ndraha, 2013:123) dalam penelitiannya menyimpulkan betapapun kuatnya budaya dan cocok untuk situasi atau lingkungan (context), tetapi tidak untuk situasi lainnya. Sehingga diperlukan dimensi lain yaitu ketepatan dan kecocokan. Budaya yang kuat namun pelaksanaannya tidak sesuai dengan situasi sesungguhnya dapat mengakibatkan orang berperilaku menghancurkan. Sehingga hanya budaya kerja yang mendukung satuan kerja atau organisasi untuk mengantisipasi dan menyesuaikan diri dengan perubahan lingkunganlah yang dapat menunjukkan kinerja yang tinggi.

Nawawi (2011:65). menjelaskan akan beberapa indikator dari budaya kerja, adalah:

1) Disiplin perilaku yang senantiasa berpijak pada peraturan dan norma

2) Keterbukaan kesiapan untuk memberi dan menerima informasi yang benar dari dan kepada sesama mitra kerja.

3) Saling menghargai perilaku yang menunjukkan penghargaan terhadap individu, tugas dan tanggung jawab orang lain sesama mitra kerja.

4) Kerjasama kesediaan untuk memberi dan menerima kontribusi dari dan kepada mitra kerja dalam mencapai sasaran dan target organisasi.

Apriyanti (2011:99) enam faktor yang mempengaruhi budaya kerja yakni inovasi, banggung jawab, orientasi pada hasil, pengetahuan, sistem kerja dan motivasi.

Barkow (2002) dalam Apriyanti (2011:100) menyebutkan bahwa faktor kemampuan beradaptasi, faktor integrasi sosial, faktor moral, serta faktor persepsi terhadap kerja merupakn faktor-faktor yang dapat mempengaruhi budaya kerja.

\subsubsection{Harapan Berkembang}

Budiman, 2010:34) menyatakan harapan adalah keadaan termotivasi yang positif didasarkan pada hubungan interaktif antara agency (energi yang mengarah pada tujuan) dan pathway (rencana untuk mencapai tujuan). Snyder, Harris, dkk (dalam Budiman, 2010:24) menjelaskan harapan sebagai sekumpulan kognitif yang didasarkan pada hubungan timbal-balik 
Menurut Snyde (1998) dalam Erwin (2009:98) harapan adalah kemampuan untuk merencanakan jalan keluar dalam upaya mencapai tujuan walaupun adanya rintangan dan menjadikan motivasi sebagai suatu cara dalam mencapai tujuan. Mas'ud (2009:89) menjelaskan harapan adalah keinginan yang belum tercapai namun masih dalam pengejaran atau masih dalam usaha untuk mencapai yang tertanam dalam hati yang akan diusahakan dalam mencapainya. Menurut Maslow (1995) dalam Handoko (2012:132) menjelaskan harapan manusia tersebut biasa termuatu dalam harapan untuk memenuhi kebutuhan manusia, seperti harapan untuk dapat memenuhi kelangsung hidup, memenuhi harapan keamanan, memenuhi harapan untuk hak dan kwajiban, memenuhi harapan diakui, perwujuan cita-cita dan harapan terpenuhi kebutuhan ekonomi. Hasibuan (2007:165) harapan (expentancy) adalah suatu kesempatan yang diberikan terjadi karena perilaku yang ingin mencapai tujuan. Jadi dapat disimpulkan harapan adalah suatu bentuk keinginan yang dikejar namun masih dalam bentuk cita-cita seseorang.

Sedangkan bila dilihat dari pengertian dari berkembang dapat diuraikan dan dijelaskan berdasarkan pendapat para ahli. Husnan dan Heidjrahman, (1999:74) berkembang atau mengembangkan diri adalah usaha-usaha untuk meningkatkan keterampilan maupun pengetahuan praktis dan penerapannya guna meningkatkan keterampilan, kecakapan, dan sikap maupun pekerjaan yang diperlukan oleh organisasi dalam usaha mencapai tujuannya. Nataly (2010:112) menjelaskan berkembang dalam karier merupakan salah satu perubahan dan peningkatan akan aktivitas kerja dalam jabatan dan karier yang mengarah kepada kemajuan terhadap suatu beban kerja.Jadi dapat disimpulkan harapan bekembang tersebut adalah suatu bentuk keinginan yang belum tercapai namun masih dalam pengejaran atau masih dalam usaha untuk mencapai yang tertanam dalam hati baik dalam bentuk jabatan maupun karier.
Menurut Snyder (2000) dalam Nataly (2010:120), komponen-komponen yang terkandung dalam teori harapan yaitu:

a. Goal Perilaku manusia adalah berorientasi dan memiliki arah tujuan. Goal atau tujuan adalah sasaran dari tahapan tindakan mental yang menghasilkan komponen kognitif.

b. Pathway Thinking untuk dapat mencapai tujuan maka individu harus memandang dirinya sebagai individu yang memiliki kemampuan untuk mengembangkan suatu jalur untuk mencapai tujuan. Proses ini yang dinamakan pathway thinking, yang menandakan kemampuan seseorang untuk mengembangkan suatu jalur untuk mencapai tujuan yang diinginkan.

c. Agency Thinking komponen motivasional pada teori harapan adalah agency, yaitu kapasitas untuk menggunakan suatu jalur untuk mencapai tujuan yang diinginkan. Agency mencerminkan persepsi individu bahwa dia mampu mencapai tujuannya melalui jalur-jalur yang dipikirkannya, agency juga dapat mencerminkan penilaian individu mengenai kemampuannya bertahan.Kombinasi Pathway Thinking dan Agency Thinking Weil (2001) dalam Nataly (2010:127) mengemukakan bahwa terdapat beberapa faktor yang dapat mempengaruhi harapan, yaitu dukungan sosial, kepercayaan religius, dan kontrol.

a. Dukungan Sosial

b. Kepercayaan Religius

c. Kontrol

Menurut Maimun (2009:213) menejelaskan faktor yang menunjang harapan seseorang dalam karier adalah:

a. Adanya keinginan untuk mencapai citacita dalam bekerja

b. Untuk meningkatkan status sosial dalam bermasyarakat

c. Memenuhi kebutuhan hidup dan keluarga

d. Mencapai kemapanan dalam berorganisasi

2.1.4. Kinerja

Basri (2011:80), kinerja bahan perbandingan antara totalitas pengeluaran 
pada waktu tertentu dibagi totalitas masukan selama periode tertentu. Kinerja juga sikap mental yang mempunyai semangat untuk bekerja keras dan ingin memiliki kebiasaan untuk melakukan peningkatan perbaikan. Menurut Mangkunegara, (2011: 67) "kinerja adalah hasil kerja secara kualitas dan kuantitas yang dicapai oleh seorang pegawai dalam melaksanakan tugasnya sesuai dengan tanggung jawab yang di berikan kepadanya. Dessler (2007) dalam Marihot, (2012:87) menyatakan bahwa penilaian kinerja atau hasil aktivitas kerja adalah memberikan umpan balik kepada karyawan dengan tujuan memotivasi para pegawai untuk menghilangkan/ meminimalkan kemerosotan kinerja/berkinerja lebih tinggi lagi. Penilaian kerja terdiri dari tiga langkah, pertama mendifinisikan pekerjaan berarti memastikan bahwa atasan dan bawahan sepakat dengan tugas-tugasnya dan standar jabatan. Kedua, menilai kinerja berarti membandingkan kinerja aktual atasan dengan standar-standar yang telah ditetapkan, dan ini mencakup beberapa jenis tingkat penilaian. Ketiga, umpan balik berarti kinerja dan kemajuan atasan dibahas dan rencana-rencana dibuat untuk pekermbangan apa saja yang dituntut. Menurut Asri, (2013:35) menjelaskan akan definisi dari kinerja suatu kegiatan yang menghasilkan sesuatu bentuk atu juga perbandingan antara totalitas pengeluaran pada waktu tertentu dibagi totalitas masukan selama periode yang terbatas.

Menurut Handoko (2012:21) ada enam metode penilaian kinerja pegawai :

a. Rating scale, evaluasi hanya didasarkan pada pendapat penilai, yang membandingkan hasil pekerjaan pegawai dengan kreteria yang dianggap penting bagi pelaksana kerja.

b. Checklist, yang dimaksudkan dengan metode ini adalah untuk mengurangi beban penilai. Penilai tinggal memilih kalimat-kalimat atau kata-kata yang menggambarkan kinerja pegawai. Penilai biasanya atasan langsung. Pemberi bobot sehingga dapat di skor. Metode ini biasa memberikan suatu gambaran prestasi kerja secara akurat, bila daftar penilai berisi item-item yang memadai.

c. Metode peristiwa kritis ( critical incident method ), penilai yang berdasarkan catatan-catatan penilai yang menggambarkan perilaku pegawai sangat baik atau jelek dalam kaitannya dengan pelaksanaan kerja. Catatancatatan ini disebut peristiwam kritis. Metode ini sangat berguna dalam memberikan umpan balik kepada pegawai dan mengurangi kesalahan kesan terakhir.

d. Metode peninjauan lapangan (field review method) seseorang ahli departemen main lapangan dan membantu para penyelia dalam penilaian mereka. Spesialis jersonalia mendapatkan informasi khusus dari atasan langsung tentang kinerja pegawai. Kemudian ahli itu mempersiapkan evaluasi atas dasar informasi tersebut. Evaluasi dikirim kepada penyelia untuk direview, perubahan, persetujuan, dan serubahan dengan pegawai yang dinilai. Spesialis personalia bias mencatat penilaian pada tipe formulir penilaian apapun yang digunakan instansi.

e. Tes dan observasi prestasi kerja, bila jumlah pegawai terbatas, penilaian prestasi kerja didasarkan pada tes pengetahuan dan keterampilan. Tes mungkin tertulis atau peragaan keterampilan. Agar berguna tes harus reliable dan valid. Metode evaluasi kelompok ada tiga : ranking, grading, point allocation method.

f. Method ranking, penilai membandingkan satu dengan pegawai lain siapa yang paling baik dan menempatkan setiap pegawai dalam urutan terbaik sampai terjelek. Kelemahan metode ini adalah kesulitan untuk menentukan faktor-faktor pembanding, subyek kesalahan kesan terakhir dan halo effect, kebaikannya menyangkut kemudahan administrasi dan penjelasannya. Grading, metode penialaian ini memisah-misahkan atau menyortir para pegawai dalam berbagai klarifikasi yang berbeda, biasanya suatu proposi tertentu harus diletakan setiap 
kategori. Point location, merupakan bentuk lain dari grading penilaian diberikan sejumlah nilai total dialokasikan diantar pegawai dalam kelompok. Para pegawai diberi nilai lebih besar dan pada para pegawai dengan kinerja lebih jelek. Kebaikan dari metode ini, penilai dapat mengevaluasi perbedaan relative diantara para pegawai, meskipun kelemahan efek halo (halo effect) dan bias kesan terakhir masih ada.

Menurut Erwin (2009:5), menyebutkan 6 (enam) faktor utama menentukan kinerja tenaga kerja, yaitu:

1) Perilaku kerja

2) Kemampuan dan keterampilan

3) Hubungan antara tenaga kerja dan pimpinan

4) Manajemen organisasi

5) Kuantitas tenaga kerja

6) Kewiraswastaan.

Menurut Gibson, et al ( dalam Srimulyo, 2009:39 ) ada tiga perangkat variable yang mempengaruhi perilaku dan prestasi kerja atau kinerja, yaitu :

a. Variabel individual, terdiri dari : kemampuan dan keterampilan mental dan fisik, latar belakang: keluarga, tingkat social, penggajian dan demografis : umur, asal-usul, jenis kelamin

b. Variable organisasional, terdiri dari : sumberdaya, kepemimpinan, imbalan, struktur dan desain pekerjaan

c. Variabel psikologis, terdiri dari : persepsi, sikap, kepribadian, belajar dan motivasi

Ada beberapa indikator dari kinerja menurut Guritno dan Waridin (2012:123) adalah mampu meningkatkan target pekerjaan, mampu menyelesaikan pekerjaan tepat waktu, mampu menciptakan inovasi dalam menyelesaikan pekerjaan, mampu menciptakan perilaku disiplin dalam bekerja dan mampu maminimalkan kesalahan pekerjaan

\subsection{Penelitian Terdahulu}

1. Yusran Akhmad, 2015, Pengaruh Budaya Kerja, Penghargaan dan Hukuman terhadap kinerja pegawai pada Pemerintah Kota Banjarbaru.
Analisis dalam penelitian ini kuantitatif dengan sampel 100 orang dengan alat uji regresi berganda dan Hasil penelitian diketahui semua variabel bebas berpengaruh signifikan dan positip terhadap kinerja pegawai. Persamaan peneliti adalah sama-sama membahas mengenai manajemen SDM dan sama dalam metode analisis yakni menggunakan regresi berganda. Perbedaannya adalah terletak pada obyek yang dijadikan sasaran penelitian, waktu penelitian, dan sasaran responden.

2. Roni Setiawan, 2014, Pengaruh Hukuman, Budaya kerja dan Penghargaan terhadap Kinerja Pegawai Pada Badan Pemberdayaan Masyarakat dan Pemerintah Desa (BPMPD) Kabupaten Banjar, analisis dalam penelitian ini kuantitatif dengan sampel 63 orang dengan alat uji regresi berganda dan semua variabel bebas berpengaruh signifikan dan positip terhadap kinerja pegawai. Persamaan peneliti adalah sama-sama membahas mengenai manajemen SDM dan sama dalam metode analisis, yakni regresi berganda. Perbedaannya adalah terletak pada obyek yang dijadikan sasaran penelitian, waktu penelitian, dan sasaran responden.

3. Hartoni (2010), Pengaruh Loyalitas, Harapan Berkembang, Budaya Kerja Terhadap Kinerja Karyawan Pada Perusahaan Daerah Air Minum Kota Surakarta. Hasil penellitian dan pembahasan dalam penelitian ini mempergunakan analisis. Sehingga dapat dinyatakan bahwa secara teoritis konstanta sebesar 3,679 menyatakan bahwa jika tidak ada X1, X2, X3, maka kinerja adalah sebesar 3,679 satuan. Angka koefisien variable loyalitas (X1) sebesar 0, 120 ; koefisien variabel harapan berkembang (X2) sebesar 0, 0448 dan koefisien variabel budaya kerja (X3) sebesar 0,444. Angka -angka tersebut diatas merupakan angka koefisien masing-masing variabel dan menunjukkan pengaruhnya terhadap variabel kinerja karyawan.

\section{BAB III}




\section{KERANGKA KONSEPTUAL DAN HIPOTESIS}

\subsection{Kerangka Konseptual}

Singarimbun (2001:45) menyatakan bahwa konsep adalah generalisasi dari sekelompok fenomena tertentu, sehingga dapat dipakai untuk menggambarkan berbagai fenomena yang sama. Kenyataannya konsep dapat mempunyai tingkat generalisasi yang berbeda, semakin dekat konsep pada realita, maka akan semakin mudah konsep tersebut diukur dan diartikan. Dalam penelitian ini yang termasuk dalam variabel bebas adalah penghargaan (reward) (X1), budaya kerja (X2) dan harapan berkembang (X3) dan masukan terhadap variabel terikat yaitu kinerja anggota kepolisian (Y). Sehubungan dengan penjelasan masalah, tujuan penelitian yang telah dikemukakan sebelumnya dan pendekatan teoritis, maka model kerangka konseptual tersebut dapat digambarkan, yaitu:

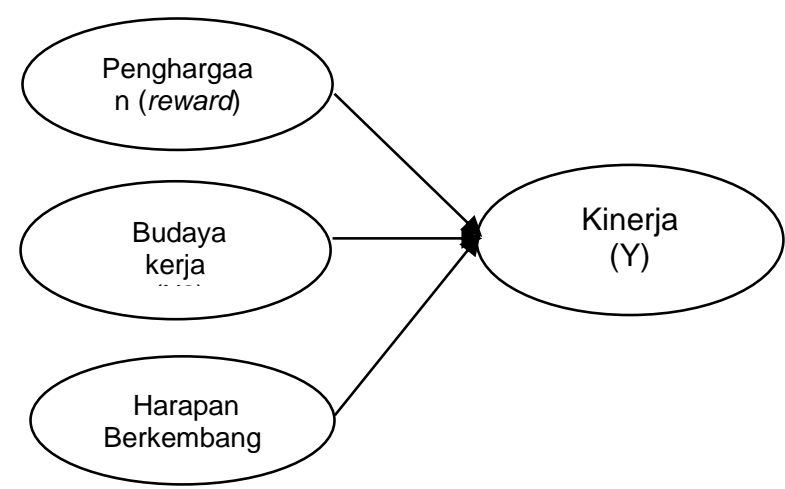

Gambar 3.1 : Kerangka Konseptual Sumber : Diolah Penulis

\subsection{Hipotesis}

Berdasarkan permasalahan yang telah disebutkan di atas, hipotesis (dugaan sementara) yang diajukan dalam penelitian ini adalah :

1. Penghargaan (reward) berpengaruh signifikan terhadap kinerja anggota kepolisian di Direktorat Reserse Kriminal Khusus (Ditreskrimsus) Polda Kalimantan Selatan.

2. Budaya kerja berpengaruh signifikan terhadap kinerja anggota kepolisian di Direktorat Reserse Kriminal Khusus (Ditreskrimsus) Polda Kalimantan Selatan.
3. Harapan berkembang berpengaruh signifikan terhadap kinerja anggota kepolisian di Direktorat Reserse Kriminal Khusus (Ditreskrimsus) Polda Kalimantan Selatan.

\section{BAB IV}

\section{METODE PENELITIAN}

\subsection{Rancangan Penelitian}

Penelitian ini adalah untuk mengetahui hubungan kausalitas antar variabel-variabel bebas dengan variabel terikat. Dengan demikian penelitian ini bersifat studi eksplorasi. Studi eksplorasi diperlukan untuk menjajaki sifat dan pola fenomena yang menarik perhatian peneliti dan merupakan usaha untuk memperoleh pengetahuan yang bermanfaat untuk pengembangan teori. Untuk menjawab pertanyaan pertanyaan yang dituangkan dalam rumusan masalah, studi eksplorasi setidaknya melakukan diagnosa terhadap fenomena pada variabel yang dilibatkan. Data yang dikumpulkan dalam studi eksplorasi ini dapat diperoleh dengan menggunakan berbagai teknik observasi dan wawancara. Tipe data yang dikumpulkan sebagian besar berupa data kualitatif. Sementara untuk mendiagnose hubungan kausalitas antar variabel terikat dengan variabel bebas dilakukan dengan metode regresi liniear berganda, untuk keperluan diagnosa tersebut data yang bersifat kualitatif harus dinyatakan secara kuantitatif dengan cara pemberian bobot skor. Pengukuran variabel dengan skor akan dijelaskan di sub bab kemudian.

\subsection{Definisi Operasional Variabel}

Adapun variabel-variabel yang akan dikumpulkan dalam penelitian ini adalah:

1. Penghargaan (reward) (X1) menurut Mahmud (2011:58), reward (hadiah) adalah bentuk penghargaan yang diberikan oleh instansi/organisasi atas keberhasilan pegawai dalam melakukan sesuatu dan menurut Halim dan Husnul (2012:111) menjelaskan alat-alat untuk memberikan penghargaan kerja adalah :

a. Pemberian dalam bentuk materiil insentif

b. Non materiil insentif 
c. Kombinasi materiil dan nonmateriil insentif

2. Budaya kerja (X2) menurut Dimas (2011:56) merupakan suatu falsafah yang didasari oleh pandangan hidup sebagai nilai-nilai yang menjadi sifat, kebiasaan dan kekuatan pendorong, membudaya dalam kehidupan suatu kelompok masyarakat atau organisasi yang tercermin dari sikap menjadi perilaku, kepercayaan, cita-cita, pendapat dan tindakan yang terwujud sebagai aktifitas dalam bekerja dan Nawawi (2011:65). Indikatornya adalah:

a. Disiplin perilaku yang senantiasa berpijak pada peraturan dan norma

b. Keterbukaan kesiapan untuk memberi dan menerima informasi yang benar dari dan kepada sesama mitra kerja.

c. Saling menghargai perilaku yang menunjukkan penghargaan terhadap individu, tugas dan tanggung jawab orang lain sesama mitra kerja.

d. Kerjasama kesediaan untuk memberi dan menerima kontribusi dari dan kepada mitra kerja dalam mencapai sasaran dan target organisasi.

3. Harapan berkembang (X3) menurut Mas'ud (2009:89) menjelaskan harapan adalah keinginan yang belum tercapai namun masih dalam pengejaran atau masih dalam usaha untuk mencapai yang tertanam dalam hati yang akan diusahakan dalam mencapainya. Indikatornya Menurut Maimun (2009:213) menejelaskan faktor yang menunjang harapan seseorang dalam karier adalah:

a. Adanya keinginan untuk mencapai cita-cita dalam bekerja

b. Untuk meningkatkan status sosial dalam bermasyarakat

c. Memenuhi kebutuhan hidup dan keluarga

d. Mencapai kemapanan dalam berorganisasi

4. Kinerja (Y) menurut Basri (2011:80) bahan perbandingan antara totalitas pengeluaran pada waktu tertentu dibagi totalitas masukan selama periode tertentu. Kinerja juga sikap mental yang mempunyai semangat untuk bekerja keras dan ingin memiliki kebiasaan untuk melakukan peningkatan perbaikan. dan indikator kinerja karyawan menurut Guritno dan Waridin (2012:123) adalah

a. Mampu meningkatkan target pekerjaan

b. Mampu menyelesaikan pekerjaan tepat waktu

c. Mampu menciptakan inovasi dalam menyelesaikan pekerjaan

d. Mampu menciptakan perilaku disiplin dalam bekerja

e. Mampu maminimalkan kesalahan pekerjaan

\subsection{Jenis dan Sumber Data}

\subsubsection{Jenis Data}

Adapun jenis data dalam penelitian ini yang penulis ambil, yaitu sebagai berikut:

1. Data Kualitatif, yaitu berupa data atau informasi yang tidak berbentuk angka, yakni berupa data tentang sejarah instansi, struktur organisasi, bidang operasional yang dilakukan atau proses kerja.

2. Data Kuantitatif, yaitu data yang berbentuk angka, yang diangkat dari dokumen-dokumen instansi dalam hal ini tentang data jumlah pegawai, data tabulasi dan data lain yang berhubungan dengan penelitiaan.

\subsubsection{Sumber Data}

Adapun sumber data dalam penelitian ini adalah sebagai berikut, yaitu:

1. Data primer, yaitu data yang diperoleh langsung dari penyebaran kuisioner kepada anggota polisi di Ditreskrimsus Polda Kalimantan Selatan.

2. Data sekunder, berupa data dan informasi pendukung yang diperoleh dan diolah dari sumber internal instansi dan literatur serta buku pendukung.

\subsection{Populasi dan Sampel}

\subsubsection{Populasi Penelitian}

Dalam penelitian ini juga akan ditentukan besar populasi yang digunakan. Dimana menurut Arikunto, (2011:221) populasi adalah keseluruhan subyek penelitian. Populasi dari penelitian ini adalah 111 orang anggota polisi di Ditreskrimsus Polda Kalimantan Selatan.

\subsubsection{Sampel Penelitian}


Menurut Sekaran (2009:77) untuk menentukan sampel sebaiknya ukuran sampel diantara 30 sampai 500 elemen sampel. Metode yang digunakan dalam pengambilan sampel penelitian ini mengunakan metode probability sampling.Menurut Arikunto, (2013:62) apabila populasi kurang dari 100 orang, maka semua akan menajdi sampel, jika populasi lebih dari 100, maka akan diambil 5\%-10\% atau 20\%-35\% atau lebih dari jumlah populasi, maka berdasarkan pendapat ini, maka sampel dalam penelitian ini ditetukan sebanyak $32 \%$ dari jumlah responden atau sebesar 35,52 atau dibulatkan menjadi 36 orang responden dan metode yang digunakan dalam pengambilan sampel penelitian ini menggunakan metode sensus.

\subsection{Teknik Pengumpulan Data}

1. Observasi, yaitu pengumpulan data melalui pengamatan secara umum anggota polisi sebagai dasar untuk mengindentifikasi permasalahan yang akan dibahas.

2. Wawancara, yaitu mengumpulkan data dengan mengadakan tanya jawab secara lisan dengan pihak anggota polisi pada waktu yang telah ditentukan.

3. Dokumentasi, yaitu teknik pengumpulan data melalui pencatatan dan pengumpulan data instansi yang berkaitan dengan permasalahan.

4. Studi kepustakaan, yaitu pengumpulan data melalui atau mempelajari berbagai literatur dan bahan bacaan lainnya yang berhubungan dengan permasalahan yang akan dibahas.

5. Kuisioner, yaitu pengumpulan data dengan cara membagikan daftar pertanyaan secara tertulis kepada anggota polisi untuk memperoleh data primer yang diperlukan dalam penyusunan tesis ini. Kuisioner yang digunakan penulis adalah kuisioner langsung dimana peneliti langsung membagikan kuisioner kepada responden dan responden diminta untuk mengisi. Sedangkan menurut jenis dalam penyusunan itemnya digunakan kuisioner tipe pilihan dimana responden memilih salah satu jawaban yang tersedia. Tujuan dilakukannya penyebaran kuisioner langsung kepada anggota polisi tersebut adalah untuk memperoleh informasi yang relevan sesuai dengan tujuan penelitian dan untuk memperoleh informasi mengenai suatu masalah secara maksimal. Untuk menentukan skor jawaban digunakan skala likert, yaitu yang digunakan untuk mengukur sikap, pendapatan dan persepsi seseorang atau kelompok orang tentang fenomena sosial. Jawaban instrumen yang menggunakan skala likert.

\subsection{Teknik Analisis Data}

Penelitian ini berdasarkan jenis data, merupakan penelitian asosiatif dengan paradigma kuantitatif. Penelitian ini bertujuan untuk mengetahui hubungan antara dua variabel atau lebih dengan menggunakan data numerik. Bentuk hubungan variabel pada penelitian ini berupa hubungan kausal (sebab-akibat), yang ditunjukkan dengan pengaruh variabel independen terhadap variabel dependen. Penelitian ini bertujuan untuk memperoleh kejelasan hubungan antar variabel dengan menggunakan perhitungan statistik dengan program SPSS 17. Adapun alat uji yang digunakan dalam penelitian ini adalah sebagai berikut

\subsubsection{Uji Instrumen \\ 1. Uji Validitas}

Alat (instrument) dapat menjawab tujuan penelitian. Pengambilan keputusan untuk valid instrumen terhadap pertanyaan adalah menurut Sulistyo (2009:44), sebagai berikut:

a. Jika rhitung positif dan rhitung > rtabel maka instrument valid.

b. Jika rtabel negative dan rhitung < rtabel maka instrument tidak valid.

\section{Uji Reliabilitas}

Selain itu variabel dikatakan reliabel jika memberikan nilai Cronbach $A_{\text {lpha }}>0,60$. (Ghozali, 2009, 41-42). Setelah dilakukan pengujian reliabilitas maka hasil dari jawaban kuesioner adalah reliabel.

\subsubsection{Uji Asumsi Klasik}

1. Uji Multikolinearitas

Multikolinearitas, adalah deteksi terhadap gangguan multikolinearitas dapat dilihat 
dari nilai VIF (variance inflation factor) dan nilai tolerance. Tolerance menguur variabilitas variable bebas yang terpilih yang tidak dapat dijelaskan oleh variable bebas lainnya. Jadi ilai tolerance yang rendah sama dengan nilai VIF tinggi (karena VIF $=1 /$ tolerance) dan menunjukkan adanya koloniritas yang tinggi. Multikolineritas dapat diketahui dengan memeriksa nilai VIF (variance inflation factor) yang merupakan unsur diagonal invers matrk korelasi sederhana antara perubah bebas. Apabila beberapa nilai VIF lebih dari 10 maka multikolienearitas adalah sebuah masalah.

\section{Uji Heteroskedastisitas}

Jika diagram pencar yang membentuk polapola tertentu yang teratur maka regresi mengalami gangguan heteroskedastisitas. Jika diagram pencar tidak membentuk pola atau acak maka regresi tidak mengalami gangguan heteroskedastisitas.

\section{Uji Normalitas (kenormalan)}

Pemeriksanaan asumsi normalitas dapat dilakukan dengan cara membuat plot antara skor normal dengan data observasi dan melihat penyebaran data (titik) pada sumbu diagonal dari grafik. Bilamana hasil plot menujukkan pola garis lurus mendekati $45^{\circ}$ berarti asumsi normalitas terpenuhi.

\subsubsection{Analisis Regresi Linier Berganda}

Analisis data dilakukan berdasarkan data primer yang diperoleh langsung dari penyebaran kuisioner kepada anggota polisi yang selanjutnya akan dianalisis dengan paket program SPSS for windows melalui bantuan program komputer. Untuk menguji hipotesa dalam penelitian ini menggunakan analisis regresi linier berganda. Rumus dari regresi linier berganda adalah:

$$
\mathrm{Y}=\mathbf{a}+\boldsymbol{\beta 1} \mathbf{. X 1}+\boldsymbol{\beta 2 . X 2}+\beta 3 . \mathrm{X3}+\varepsilon
$$

Dimana :

$\mathrm{Y}=$ Kinerja anggota kepolisian

$\mathrm{X}_{1}=$ Penghargaan (reward)

$\mathrm{X}_{2}=$ Budaya kerja

$\mathrm{X}_{3}=$ Harapan berkembang

$\mathrm{E}=$ Faktor gangguan

$\beta_{1,2,3}=$ Koefsien regresi

$\mathrm{a}=$ Konstanta

\subsubsection{Uji Hipotesis}

1. Uji t (parsial)
Uji $\mathrm{t}$ dilakukan untuk menguji tingkat signifikan variabel bebas (X) secara individu/parsial terhadap variabel terikat (Y). Adapun langkah-langkah pengujian sebagai berikut Menentukan taraf nyata dan $\mathrm{t}$ table Taraf nyata 5\% $(0,05)$ Pada t table $\mathrm{db}$ $=\mathrm{n}-\mathrm{k}$ dengan kreteria pengujian apabila $\mathrm{t}-$ hitung > t-tabel, maka $\mathrm{H}_{0}$ ditolak atau $\mathrm{H}_{1}$ diterima dan apabila t-hitung < t-tabel, maka $\mathrm{H}_{0}$ diterima atau $\mathrm{H}_{1}$ ditolak.

\section{Uji F (simultan)}

Menentukan taraf nyata dan $\mathrm{F}$ table, taraf nyata $5 \%(0,05)$ Derajat pembilang $\left(\mathrm{db}_{1}\right)=$ $\mathrm{k}-1$; Derajat penyebut $\left(\mathrm{db}_{2}\right)=\mathrm{n}-\mathrm{k}$ engan kreteria pengujian apabila F-hitung > Ftabel, maka $\mathrm{H}_{0}$ ditolak atau $\mathrm{H}_{1}$ diterima. dan apabila F-hitung < F-tabel, maka $\mathrm{H}_{0}$ diterima atau $\mathrm{H}_{1}$ ditolak.

\section{Uji Variabel Dominan}

Untuk mengkaji variabel yang dominan digunakan indikator koefisien beta standardized dari variabel-variabel dari model regresi. Koefisien beta standardized diperoleh dari hasil perkalian antara koefisien parsial korelasi ( $\left.\mathrm{SDx}_{1} / \mathrm{Sdy}\right)$ dan koefisien variabelnya (bi).

\section{BAB V}

ANALISIS HASIL PENELITIAN DAN PEMBAHASAN

\subsection{Analisis Hasil Penelitian}

\subsubsection{Analisis Uji Instrumen Penelitian}

\section{Uji Validitas}

Adapun uji validitas atas instrument didalam penelitian ini sebagai berikut:

1) Variabel Penghargaan $\left(X_{1}\right)$

\section{Tabel 5.9}

Hasil Uji Validitas Penghargaan ( $\left.\mathbf{X}_{1}\right)$

\begin{tabular}{|c|c|c|}
\hline Variable & $\begin{array}{c}\text { rhitung } \\
\text { (lihat lamp 3) }\end{array}$ & $\begin{array}{c}\text { rtabel } \\
\text { (lihat lamp 6) }\end{array}$ \\
\hline $\mathrm{X}_{1.1}$ & $0,470(* *)$ & 0,334 \\
$\mathrm{X}_{1.2}$ & $0,570\left(^{* *}\right)$ & 0,334 \\
$\mathrm{X}_{1.3}$ & $0,611\left(^{* *}\right)$ & 0,334 \\
\hline
\end{tabular}

Sumber : data primer diolah

Berdasarkan hal itu bila dibandingkan antara rhitung dengan rtabel tersebut, maka dapat disimpulkan bahwa semua instrumen pertanyaan tersebut valid, ini terbukti nilai rhitung positip dan rhitung > rtabel, maka semua instrumen dari pertanyaan yang di ajukan terhadap variabel penghargaan $\left(\mathrm{X}_{1}\right)$ tersebut valid.

2) Variabel Budaya Kerja $\left(X_{2}\right)$ 
Tabel 5.10

Hasil Uji Validitas Budaya Kerja $\left(\mathbf{X}_{2}\right)$

\begin{tabular}{|c|c|c|}
\hline Variable & $\begin{array}{c}\text { rhitung } \\
\text { (lihat lamp 3) }\end{array}$ & $\begin{array}{c}\text { rtabel } \\
\text { (lihat lamp 6) }\end{array}$ \\
\hline $\mathrm{X}_{2.1}$ & $0,444(* *)$ & 0,334 \\
$\mathrm{X}_{2.2}$ & $0,548(* *)$ & 0,334 \\
$\mathrm{X}_{2.3}$ & $0,479(* *)$ & 0,334 \\
$\mathrm{X}_{2.4}$ & $0,488(* *)$ & 0,334 \\
\hline
\end{tabular}

Berdasarkan hal itu bila dibandingkan antara rhitung dengan rtabel tersebut, maka dapat disimpulkan bahwa semua instrumen pertanyaan tersebut valid, ini terbukti nilai rhitung positip dan rhitung > rtabel, maka semua instrumen dari pertanyaan yang diajukan terhadap variabel budaya kerja $\left(\mathrm{X}_{2}\right)$ tersebut valid.

3) Variabel Harapan Berkembang $\left(\mathbf{X}_{3}\right)$ Tabel 5.11

Uji Validitas Harapan Berkembang ( $\left.\mathbf{X}_{3}\right)$

\begin{tabular}{|c|c|c|}
\hline Variable & $\begin{array}{c}\text { rhitung } \\
\text { (lihat lamp 3) }\end{array}$ & $\begin{array}{c}\text { rtabel } \\
\text { (lihat lamp 6) }\end{array}$ \\
\hline $\mathrm{X}_{3.1}$ & $0,496(* *)$ & 0,334 \\
$\mathrm{X}_{3.2}$ & $0,590(* *)$ & 0,334 \\
$\mathrm{X}_{3.3}$ & $0,490(* *)$ & 0,334 \\
$\mathrm{X}_{3.4}$ & $0,504(* *)$ & 0,334 \\
\hline
\end{tabular}

Sumber :data primer diolah

Berdasarkan hal itu bila dibandingkan antara rhitung dengan rtabel tersebut, maka dapat disimpulkan bahwa semua instrumen pertanyaan tersebut valid, ini terbukti nilai rhitung positip dan rhitung > rtabel, maka semua instrumen dari pertanyaan yang di ajukan terhadap variabel harapan berkembang $\left(\mathrm{X}_{3}\right)$ tersebut valid.

\section{4) Variabel Kinerja Anggota Kepolisian (Y)}

Tabel 5.12

Hasil Uji Validitas Kinerja (Y)

\begin{tabular}{|c|c|c|}
\hline Variable & $\begin{array}{c}\text { rhitung } \\
\text { (lihat lamp 3) }\end{array}$ & $\begin{array}{c}\text { rtabel } \\
\text { (lihat lamp 6) }\end{array}$ \\
\hline Y1.1 & $0,497(* *)$ & 0,334 \\
Y1.2 & $0,451(* *)$ & 0,334 \\
Y1.3 & $0,590(* *)$ & 0,334 \\
Y1.4 & $0,492(* *)$ & 0,334 \\
Y1.5 & $0,498(* *)$ & 0,334 \\
\hline
\end{tabular}

Sumber :data primer diolah

Berdasarkan hal itu bila dibandingkan antara rhitung dengan rtabel tersebut, maka dapat disimpulkan bahwa semua instrumen pertanyaan tersebut valid, ini terbukti nilai rhitung positip dan rhitung > rtabel, maka semua instrumen dari pertanyaan variabel kinerja anggota kepolisian (Y) valid.

\section{Uji Reliabilitas}

Berikut ringkasan hasil uji reliabilitas instrumen dalam penelitian ini.

Tabel 5.13

Hasil Uji Reliabilitas

\begin{tabular}{|l|c|c|}
\hline \multicolumn{1}{|c|}{ Variabel } & $\begin{array}{c}\text { Cronbach's } \\
\text { Alpha } \\
\text { (lihat lamp 4) }\end{array}$ & $\begin{array}{c}\text { Data } \\
\text { baku }\end{array}$ \\
\hline Penghargaan $\left(\mathrm{X}_{1}\right)$ & 0,686 & 0,60 \\
Budaya Kerja $\left(\mathrm{X}_{2}\right)$ & 0,659 & 0,60 \\
Harapan & 0,706 & 0,60 \\
Berkembang (X & 0,664 & 0,60 \\
Kinerja anggota & 0,664 & \\
kepolisian (Y) & & \\
\hline
\end{tabular}

Sumber: data primer diolah

\subsubsection{Uji Asumsi Klasik}

\section{Uji Multikolinieritas}

Deteksi terhadap ada tidaknya multikolinieritas, yaitu dapat diketahui dengan melihat pada nilai tolerance dan variance inflation factor (VIF). Nilai tolerance dan nilai variance inflation factor (VIF) suatu model regresi yang dinyatakan bebas dari masalah multikolinieritas apabila mempunyai nilai tolerance mendekati 1 dan nilai VIF tidak lebih dari 10.

Tabel 5.14

Hasil Uji Multikolinieritas

\begin{tabular}{|l|c|c|}
\hline \multirow{2}{*}{ Variabel } & \multicolumn{2}{|c|}{$\begin{array}{c}\text { Collinierarit } \\
\text { y Statistic's } \\
\text { (lihat lampiran 5) }\end{array}$} \\
\cline { 2 - 3 } & Tolerance & VIF \\
\hline $\begin{array}{l}\text { Penghargaan } \\
\left(\mathrm{X}_{1}\right)\end{array}$ & 0,989 & 1,056 \\
\hline $\begin{array}{l}\text { Budaya kerja } \\
\left(\mathrm{X}_{2}\right)\end{array}$ & 0,999 & 1,348 \\
\hline $\begin{array}{l}\text { Harapan } \\
\text { Berkembang } \\
\left(\mathrm{X}_{3}\right)\end{array}$ & 0,996 & 1,219 \\
\hline
\end{tabular}

Sumber: data primer diolah

Berdasarkan hasil perhitungan collinierarity statistic's pada tabel 5.14 terlihat bahwa nilai tolerance lebih besar dari $10 \%$ dan nilai variance inflation factor 
(VIF) di atas menunjukkan tidak ada satu pun variabel bebas yang memiliki nilai VIF lebih dari 10. Jadi dapat disimpulkan bahwa hasil penelitian ini tidak ada gejala multikolinieritas antar variabel bebas dalam model regresi.

\section{Uji Heteroskedastisitas}

Heteroskedastisitas dapat dideteksi dengan melihat grafik berikut init.

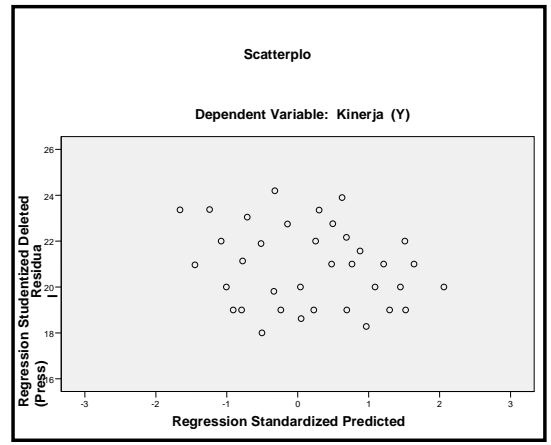

Gambar 5.2 : Scatterplot

Sumber : lampiran 5

Berdasarkan grafik scatterplots di atas ini terlihat titik-titik menyebar secara acak serta tersebar baik di atas maupun di bawah angka 0 pada sumbu $Y$. Hal ini dapat disimpulkan bahwa tidak terjadi heteroskedastisitas pada model regresi, sehingga model regresi layak dipakai untuk memprediksi variabel kinerja anggota kepolisian pada Direktorat Reserse Kriminal Khusus Polda Kalimantan Selatan berdasarkan pengaruh variabel penghargaan, budaya kerja dan harapan berkembang.

\section{Uji Normalitas}

Uji normalitas dilakukan untuk mengetahui apakah dalam model regresi variabel dependen dan variabel independen keduanya mempunyai distribusi normal. Uji normalitas, yaitu:

Normal P-P Plot of Rearession

Dependent Variable: Kinerja $(\mathrm{Y})$

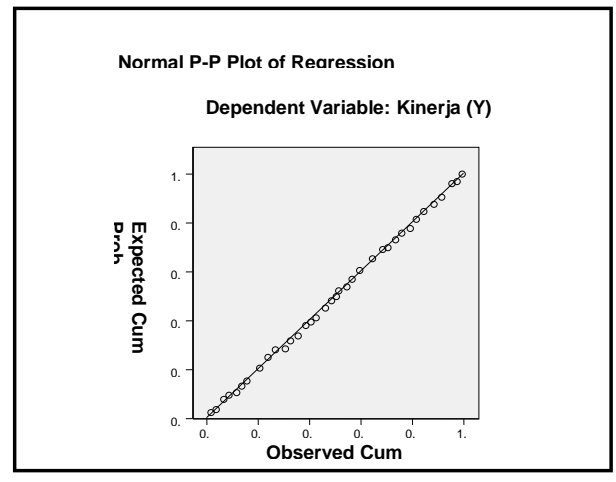

\section{Gambar 5.3 Diagram Normal P-P Plot}

Sumber: lampiran 5

Berdasarkan gambar 5.3 terlihat tampilan grafik histogram maupun grafik normal $p$ - $p$ plot yang menunjukkan bahwa grafik histogram memberikan pola distribusi yang mendekati normal, sedangkan pada grafik normal p-p plot terlihat titik-titik menyebar disekitar garis diagonal, serta penyebarannya mengikuti arah garis diagonal. Kedua grafik ini menunjukkan bahwa model regresi layak dipakai untuk memprediksi kinerja anggota kepolisian pada Direktorat Reserse Kriminal Khusus Polda Kalimantan Selatan berdasarkan masukan dari variabel penghargaan, budaya kerja dan harapan berkembang karena memenuhi uji asumsi normalitas.

\subsubsection{Analisis Regresi}

Pengujian hipotesis dalam penelitian ini dilakukan dengan Analisis Regresi Berganda untuk menentukan kontribusi relatif tiap variabel bebas dalam menjelaskan pengaruhnya terhadap variabel terikat. Untuk menguji hal tersebut, perlu dilakukan uji hipotesis dengan menggunakan uji regresi berganda melalui program spss. Untuk pengujian hipotesis secara parsial dapat dilihat melalui hasil uji regresi berganda berikut ini :

Tabel 5.15

Hasil Uji Regresi Berganda Coefficients(a)

\begin{tabular}{|c|c|c|c|c|c|c|c|}
\hline & \multicolumn{2}{|c|}{$\begin{array}{l}\text { Unstandardized } \\
\text { Coefficients }\end{array}$} & \multirow{2}{*}{$\begin{array}{c}\text { Standardized } \\
\text { Coefficients } \\
\text { Beta } \\
\end{array}$} & \multirow[b]{2}{*}{$\mathrm{t}$} & \multirow[b]{2}{*}{$\begin{array}{c}\text { Sig } \\
.\end{array}$} & \multicolumn{2}{|c|}{$\begin{array}{c}\text { Collinearity } \\
\text { Statistics }\end{array}$} \\
\hline & B & $\begin{array}{l}\text { Std. } \\
\text { Error }\end{array}$ & & & & $\begin{array}{c}\text { Toleranc } \\
\mathrm{e}\end{array}$ & VIF \\
\hline (Constant) & $\begin{array}{r}19,97 \\
8\end{array}$ & 2,123 & & $\begin{array}{r}9,41 \\
0\end{array}$ & $\begin{array}{r}, 00 \\
0\end{array}$ & & \\
\hline $\begin{array}{l}\text { Pengharga } \\
\text { an (X1) }\end{array}$ &, 792 & , 127 & ,790 & $\begin{array}{r}6,23 \\
6\end{array}$ & $\begin{array}{r}, 00 \\
2\end{array}$ & ,989 & 1,056 \\
\hline $\begin{array}{l}\text { Budaya } \\
\text { Kerja (X2) }\end{array}$ & ,899 & , 112 & ,898 & $\begin{array}{r}8,02 \\
6\end{array}$ & $\begin{array}{r}, 00 \\
0\end{array}$ & 999 & 1,348 \\
\hline $\begin{array}{l}\text { Harapan } \\
\text { Berkemba } \\
\text { ng }(X 3)\end{array}$ & ,830 & , 118 & ,830 & $\begin{array}{r}7,03 \\
3\end{array}$ & $\begin{array}{r}, 00 \\
1\end{array}$ & ,996 & 1,219 \\
\hline
\end{tabular}


a Dependent Variable: Kinerja (Y)

Sumber: data primer diolah (lihat lamp 5)

5.1.4. Uji Hipotesis Secara Parsial

Rekapitulasi tersebut dapat diolah hipotesis dalam penelitian ini sebagai berikut:

\section{Hipotesis Pertama $\left(\mathrm{H}_{1}\right)$}

Penghargaan (reward) berpengaruh signifikan terhadap kinerja anggota kepolisian di Direktorat Reserse Kriminal Khusus (Ditreskrimsus) Polda Kalimantan Selatan

Untuk mengetahui akan pengujian hipotesis secara parsial terlebih dahulu harus diketahui akan ttabel dengan cara mendapatkan ttabel digunakan tabel distribusi t untuk tingkat signifikasi 5\% dengan Degrees of Freedom (df) $=\mathrm{n}-\mathrm{k}$ maka didapat df adalah (36-4)=32 dengan demikian ttabel adalah sebesar 1,694, berdasarkan data tersebut dapat digambarkan hasil pengujian hipotesis pertama ini dengan uraian, yaitu variabel penghargaan $\left(\mathrm{X}_{1}\right)$ mempunyai pengaruh yang signifikan terhadap kinerja anggota kepolisian, dimana thitung lebih besar dari ttabel seperti thitung $=6,236>$ ttabel $=$ 1,694 , tingkat signifikansi $\mathrm{p}=0,002<0,05$. Tingkat kepercayaan yang diambil dalam penelitian ini sebesar 95\% dengan tingkat kesalahan $(\alpha)$ sebesar 5\%, ini berarti terdapat pengaruh signifikan antara variabel penghargaan $\left(\mathrm{X}_{1}\right)$ dengan variabel terikat yaitu kinerja anggota kepolisian (Y) pada Direktorat Reserse Kriminal Khusus Polda Kalimantan Selatan. Besarnya pengaruh variabel penghargaan $\left(\mathrm{X}_{1}\right)$ terhadap kinerja anggota kepolisian (Y) dapat diketahui dari Standardized Coefficients Beta 0,790 yang berarti penghargaan dapat mempengaruhi kinerja anggota kepolisian pada Direktorat Reserse Kriminal Khusus Polda Kalimantan Selatan adalah sebesar $79 \%$.

\section{Hipotesis Kedua $\left(\mathrm{H}_{2}\right)$}

Budaya kerja berpengaruh signifikan terhadap kinerja anggota kepolisian di Direktorat Reserse Kriminal Khusus (Ditreskrimsus) Polda Kalimantan Selatan Untuk mengetahui akan pengujian hipotesis secara parsial terlebih dahulu harus diketahui akan ttabel dengan cara mendapatkan ttabel digunakan tabel distribusi t untuk tingkat signifikasi $5 \%$ dengan Degrees of Freedom (df) $=\mathrm{n}-\mathrm{k}$ maka didapat df adalah $(36-4)=32$ dengan demikian ttabel adalah sebesar 1,694, berdasarkan data tersebut dapat digambarkan hasil pengujian hipotesis kedua ini dengan uraian, yaitu variabel budaya kerja $\left(\mathrm{X}_{2}\right)$ mempunyai pengaruh yang signifikan terhadap kinerja anggota kepolisian, dimana thitung lebih besar dari ttabel seperti thitung $=8,026>$ ttabel $=$ 1,694 tingkat signifikansi $p=0,000<0,05$. Tingkat kepercayaan yang diambil dalam penelitian ini sebesar $95 \%$ dengan tingkat kesalahan $(\alpha)$ sebesar $5 \%$, ini berarti terdapat pengaruh signifikan antara variabel budaya kerja $\left(\mathrm{X}_{2}\right)$ dengan variabel terikat yaitu kinerja anggota kepolisian (Y) pada Direktorat Reserse Kriminal Khusus Polda Kalimantan Selatan. Besarnya pengaruh variabel budaya kerja $\left(\mathrm{X}_{2}\right)$ terhadap kinerja anggota kepolisian (Y) dapat diketahui dari Standardized Coefficients Beta 0,898 yang berarti budaya kerja dapat mempengaruhi kinerja anggota kepolisian pada Direktorat Reserse Kriminal Khusus Polda Kalimantan Selatan adalah sebesar $89,8 \%$.

\section{Hipotesis Ketiga $\left(\mathrm{H}_{3}\right)$}

Harapan berkembang berpengaruh signifikan terhadap kinerja anggota kepolisian di Direktorat Reserse Kriminal Khusus (Ditreskrimsus) Polda Kalimantan Selatan

Untuk mengetahui akan pengujian hipotesis secara parsial terlebih dahulu harus diketahui akan ttabel dengan cara mendapatkan ttabel digunakan tabel distribusi $\mathrm{t}$ untuk tingkat signifikasi 5\% dengan Degrees of Freedom (df) $=\mathrm{n}-\mathrm{k}$ maka didapat df adalah (36-4)= 32 dengan demikian ttabel adalah sebesar 1,694, berdasarkan data tersebut dapat digambarkan hasil pengujian hipotesis ketiga ini dengan uraian, yaitu variabel harapan berkembang $\left(\mathrm{X}_{3}\right)$ mempunyai pengaruh yang signifikan terhadap kinerja anggota kepolisian, dimana thitung lebih besar dari ttabel seperti thitung $=7,033>$ ttabel $=1,694$, tingkat signifikansi $\mathrm{p}=0,001$ $<0,05$. Tingkat kepercayaan yang diambil dalam penelitian ini sebesar $95 \%$ dengan tingkat kesalahan $(\alpha)$ sebesar 5\%, ini berarti terdapat pengaruh signifikan antara variabel 
harapan berkembang $\left(\mathrm{X}_{3}\right)$ dengan variabel terikat yaitu kinerja anggota kepolisian (Y) pada Direktorat Reserse Kriminal Khusus Polda Kalimantan Selatan. Besarnya pengaruh variabel harapan berkembang $\left(\mathrm{X}_{3}\right)$ terhadap kinerja anggota kepolisian (Y) dapat diketahui dari Standardized Coefficients Beta 0,830 yang berarti harapan berkembang dapat mempengaruhi kinerja anggota kepolisian pada Direktorat Reserse Kriminal Khusus Polda Kalimantan Selatan adalah sebesar $83 \%$.

\subsubsection{Uji Hipotesis Secara Simultan}

Selain itu dalam penelitian ini dapat juga diketahui pengaruh secara bersama-sama antara variabel bebas dengan variabel terikat dengan cara menilai Ftabel dengan tingkat signifikan 5\%. Derajat bebas bagi pembilang (numerator) adalah (k-1) sehingga didapat $(4-1)=3$, sedangkan derajat kebebasan bagi pembagi (denumerator) adalah (n-k) sehingga didapat $(36-4)=32$. Dengan demikian didapat Ftabel dengan numerator $=3$ dan denumurator 32 sebesar 2,901.Kemudian untuk mengetahui akan Fhitung dapat diketahui melalui data pada tabel berikut ini:

Tabel 5.16

Hasil Uji Regresi ANOVA(b)

\begin{tabular}{|c|c|c|c|c|c|}
\hline \multicolumn{2}{|c|}{ Model } & $\begin{array}{c}\text { Sum of } \\
\text { Squares }\end{array}$ & $\mathrm{df}$ & F & Sig. \\
\hline \multirow[t]{3}{*}{1} & Regression & 122,834 & 3 & 7,855 & ,000 \\
\hline & Residual & 17,201 & 33 & & \\
\hline & Total & 140,035 & 36 & & \\
\hline
\end{tabular}

a Predictors: (Constant), Budaya Kerja

(X2) Penghargaan (1), Harapan

Berkembang (X3)

b Dependent Variable: Kinerja (Y)

Sumber : Lampiran 5

Kemudian dilanjutkan dalam pengujian. Hasil pengujian hipotesis secara simultan dengan $\mathrm{n}=36$ menunjukkan bahwa variabel bebas secara simultan berpengaruh terhadap variabel terikat, dimana Fhitung lebih besar dari Ftabel (Fhitung $=7,855>$ Ftabel $=$ 2,901) dan tingkat signifikansi $p=0,000<$ 0,05 . Tingkat kepercayaan yang diambil dalam penelitian ini sebesar $95 \%$ dengan tingkat kesalahan $(\alpha)$ sebesar 5\%. Dengan demikian dapat disimuplkan uji hipotesis secara simultan diketahui bahwa variabel bebas berpengaruh terhadap variabel terikat.Uji Selanjutnya adalah untuk mengetahui uji determinan dari besarnya hubungan yang signifikan terhadap variabel terikat dengan variabel bebas secara dapat dilihat melalui tabel berikut ini:

Tabel 5.17

Hasil Uji Regresi Model Summary(b)

\begin{tabular}{|l|r|r|r|r|r|}
\hline Model & $\mathrm{R}$ & $\begin{array}{c}\mathrm{R} \\
\text { Square }\end{array}$ & $\begin{array}{c}\text { Adjusted } \\
\text { R Square }\end{array}$ & $\begin{array}{c}\text { Std. Error } \\
\text { of the } \\
\text { Estimate }\end{array}$ & $\begin{array}{c}\text { Durbin- } \\
\text { Watson }\end{array}$ \\
\hline 1 &, 877 (a) &, 789 &, 773 & 12,681 & 2,190 \\
\hline
\end{tabular}

a Predictors: (Constant), Budaya Kerja

(X2) Penghargaan (1), Harapan

Berkembang (X3)

b Dependent Variable: Kinerja (Y)

Sumber : Lampiran 5

Berdasarkan data tersebut, uji determinan dalam penelitian ini dapat dilihat dari nilai Multiple $\mathrm{R}$ yaitu sebesar 0,877 yang mendekati angka 1 sedangkan variabel bebas tersebut mampu menjelaskan perubahan kinerja anggota kepolisian pada Direktorat Reserse Kriminal Khusus Polda Kalimantan Selatan dapat dilihat dari nilai R Square sebesar 78,9\% $(\mathrm{R} 2=0,789)$ hal ini menjelaskan adanya hubungan yang sangat kuat antara variabel bebas dengan variabel terikat sedangkan sisanya sebesar $21,1 \%$ atau 0,211 dipengaruhi oleh variabel lain yang tidak termasuk dalam penelitian ini seperti variabel pola kepemimpinan,manajemen keorganisasian, tingkat pendidikan dan lain-lain.

\subsection{Pembahasan}

1. Penghargaan (reward) berpengaruh signifikan terhadap kinerja anggota kepolisian di Direktorat Reserse Kriminal Khusus (Ditreskrimsus) Polda Kalimantan Selatan

Sejalan dengan hal tersebut, maka hendaknya pihak Direktorat Reserse Kriminal Khusus (Ditreskrimsus) Polda Kalimantan Selatan dapat lebih memperhatikan kembali akan prestasi dari anggotanya maupun kepada anggota yang mempunyai pengabdian dan jasa yang tinggi terhadap institusi kepolisian, adapun bentuk penghargaan yang dapat diberikan, yaitu: 
a. Pemberian dalam bentuk materiil insentif, peneliti menyarankan untuk memberikan penghargaan atas anggota polisi yang berprestasi dan telah berjasa terhadap institusi kepolisian dengan memberikan berupa uang dan atau barang berupa kendaraan pribadi ataupun dalam bentuk rumah rumah pribadi dengan harapan anggota polisi dapat bekerja lebih baik lagi, karena mereka merasa diperhatikan dan dihargai hasil kinerja mereka.

b. Selain itu bentuk penghargaan kepada anggota polisi yang berprestasi dan berjasa terhadap institusi kepolisian hendaknya diberikan penghargaan non materiil insentif, yaitu alat penghargaan yang diberikan berupa mendali, piagam, bintang jasa, dan lain-lain agar mereka merasa diperhatikan dan dihargai hasil kinerja mereka.

c. Kemudian kepada anggota polisi yang berprestasi dan berjasa terhadap institusi kepolisian hendaknya diberikan penghargaan lain yang dapat juga diberikan berupa kenaikan pangkat maupun diberikan jabatan

2. Budaya kerja berpengaruh signifikan terhadap kinerja anggota kepolisian di Direktorat Reserse Kriminal Khusus (Ditreskrimsus) Polda Kalimantan Selatan

Sejalan dengan hal tersebut, Direktorat Reserse Kriminal Khusus (Ditreskrimsus) Polda Kalimantan Selatan perlu memperhatiakn kembali budaya-budaya kerja yan selama ini berjalan dan yang ada dilingkungan Direktorat Reserse Kriminal Khusus (Ditreskrimsus) Polda Kalimantan Selatan, apabila terdapat budaya kerja yang baik, hendaknya lebih ditingkatkan kembali, sedangkan apabila terdapat budaya kerja yang kurang baik hendaknya dan perlu dievaluasi, diperbaiki dan dikembangkan lagi agar menjadi budaya kerja yang baik. Adapun usaha yang dapat dilakukan oleh pihak Direktorat Reserse Kriminal Khusus (Ditreskrimsus) Polda Kalimantan Selatan agar dapat membentuk budaya yang baik dan postip dilingkungan kerja, sebagai berikut: a. Selalu berusaha menciptakan dan menanamkan kepada segenap anggota kepolisian untuk selalu disiplin dalam bekerja serta disiplin dalam berperilaku yang senantiasa berpijak pada peraturan dan norma, untuk mendukung hal ini perlu ada sangsi tegas apabila ada anggota yang melanggar, sehingga hal ini dapat menjadi budaya yang baik untuk selalu dikembangkan.

b. Ciptakan keterbukaan dalam bekerja dalam hal selalu siap memberi dan menerima informasi yang benar dari dan kepada sesama mitra kerja.

c. Saling menghargai perilaku yang menunjukkan penghargaan terhadap individu, tugas dan tanggung jawab orang lain sesama mitra kerja.

d. Kerjasama kesediaan untuk memberi dan menerima kontribusi dari dan kepada mitra kerja dalam mencapai sasaran dan target organisasi.

Terkait dengan hasil penelitian ini budaya kerja merupakan variabel dominan yang mempengaruhi kinerja anggota kepolisian, hal ini jelas budaya kerja merupakan hal yang sangat penting dibanding dengan variabel lain karena budaya itu suatu bentuk kebiasaan, apabila didalam organisasi sudah terbentuk budaya kerja yang sehat atau budaya yang bersih, budaya disiplin dalam bekerja maupun terciptanya budaya yang ikhlas dalam bekerja, maka seorang anggota polisi akan mempunyai komitmen dan loyalitas yang baik dalam bekerja, mereka bekerja tidak akan lagi untuk mengejar jabatan maupun penghargaan, hal ini disebabkan anggota polisi mempunyai budaya kerja yang baik, dengan budaya kerja yang baik maka mereka bekerja akan ikhlas sesuai dengan beban dan tanggungjawab yang diamanahkah, namun apabila sebaliknya didalam organisasi kepolisian sudah terbentuk budaya kerja yang tidak sehat, maka hal tersebut akan membentuk para anggota polisi yang tadinya baik akan terpengaruh oleh budaya yang tidak sehat dilingkungan mereka bekerja, sehingga mempengaruhi komitmen dan loyalitas anggota polisi dalam bekerja yang akhirnya kinerja mereka menjadi kurang maksimal. Jadi budaya kerja yang 
baik dilingkungan organisasi akan membentuk anggotanya menjadi baik pula, sebaliknya apabila budaya kerja terbentuk menjadi kurang baik maka akan membentuk kinerja anggota polisi menjadi kurang baik pula. Oleh sebab itulah mengapa budaya kerja ini lebih penting dan mempunyai pengaruh yang dominan terhadap kinerja anggota polisi dibanding dengan dengan variabel pengahargaan dan harapan berkembang.

3. Harapan berkembang berpengaruh signifikan terhadap kinerja anggota kepolisian di Direktorat Reserse Kriminal Khusus (Ditreskrimsus) Polda Kalimantan Selatan.

Berdasarkan hal tersebut, maka hendaknya pihak Direktorat Reserse Kriminal Khusus (Ditreskrimsus) Polda Kalimantan Selatan dapat memberikan peluang yang seluasluasnya kepada anggota kepolisian untuk berkembang dalam karier dan pangkat. Adapun faktor yang perlu diperhatikan dalam memberikan harapan berkembang baik karier maupun pangkat kepada anggota kepolisian dengan melihat kemamampuan mereka dalam meningkatkan target pekerjaan, kemamampuan menyelesaikan pekerjaan tepat waktu, kemampuan anggota menciptakan inovasi dalam menyelesaikan pekerjaan, kemampuan anggota menciptakan perilaku disiplin dalam bekerja dan kemampuan anggota maminimalkan kesalahan pekerjaan. Dengan prestasi yang dicapai tersebut, maka wajar saja para anggota kepolisian tersebut diberikan reasliasi terhadap harapan mereka dalam berkembang dalam karier dan kepangkatan. Selain itu usaha yang dapat dilakukan untuk memberikan dan merealisasi kan harapan berkembang dari anggota kepolisian adalah selalu membina dan mendidik serta selalu mengembangkan kompetensi para anggota kepolisian melalui peningkatan pendidikan maupun memberikan pelatihan-pelatihan. Bila dilihat dari hasil penelitian diketahui bahwa variabel yang dominan dalam mempengaruhi kinerja anggota kepolisian di Direktorat Reserse Kriminal Khusus (Ditreskrimsus) Polda Kalimantan Selatan adalah variabel budaya kerja, untuk itu hendaknya pihak Direktorat Reserse Kriminal Khusus (Ditreskrimsus) Polda Kalimantan Selatan dapat lebih memperhatikan, meningkatkan dan menerapkan akan budaya kerja yang ada dilingkungan organisasi, seperti budaya disiplin dalam bekerja, budaya jujur dalam bekerja, budaya komunikasi yang terbuka, budaya saling bekerjasama dalam bekerja maupun menciptakan budaya yang harmonis dalam bekerja. Budaya kerja sangat penting dalam menunjang kinerja, karena budaya merupakan suatu kebiasaan dan kebiasaan itu akan sulit untuk dirubah dan diperbaiki, untuk itulah pengelolaan dan penanaman budaya kerja yang baik sangat dan harus selalu ditanamkan kepada para anggota kepolisian serta suri tauladan dari jajaran petinggi di dilingkungan Direktorat Reserse Kriminal Khusus (Ditreskrimsus) Polda Kalimantan Selatan juga sangat diharapkan. Harapan dengan diciptakannya budaya kerja yang baik dapat meningkatkan kinerja anggota kepolisian kearah yang lebih baik, seperti meningkatnya inovasi dalam bekerja, meningkatnya rasa tanggung jawab dalam bekerja, para anggota polisi bekerja selalu berorientasi pada hasil, sistem kerja dapat berjalan sesuai harapan dan dapat memacu semangat dan gairah anggota polisi dalam bekerja.

\section{DAFTAR PUSTAKA}

As'ad, 2010, Penghantar Ilmu Manajemen, BPFE Yogyakarta

Arikunto Suharsimi, 2013, Prosedur Penelitian Suatu Pendekatan dan Praktek, Rineka Cipta, Jakarta

Asri, 2013, Manajamen, Pustaka Setia, Jakarta

Apriyanti, 2011, Budaya Organsasi, Rineka Cipta, Jakarta

Budiman, 2010, Perilaku Keorganisasian, Rineka Cipta, Jakarta

Basri. L, 2011, Manajemen, PT. Rajawali Press, Jakarta 
Danim, 2009, Manajemen Sumber Daya Manusia, PT. Rajawali Press, Jakarta

Dimas.S, 2011, Budaya Kerja, Rineka Cipta, Jakarta

Eko.S, 2013, Budaya Kerja, Liberty, Jakarta Erwin. T, 2009, Psikologi Bisnis, Alma Pres, Jakarta

Guritno dan Waridin, 2012, Pengantar Ilmu Manajemen Perusahaan, Rineka cipta, Jakarta

Ghozali, 2009, Metode Penelitian, PT. Rajawali Pres, Jakarta

Hartoni, 2010, Pengaruh Loyalitas, Harapan Berkembang, Budaya Kerja Terhadap Kinerja Karyawan Pada Perusahaan Daerah Air Minum Kota Surakarta, Universitas Surabaya, Surabaya

Handoko.T.H, 2012, Manajemen Personalia dan Sumber Daya Manusia, Edisi Revisi, Penerbit BPFE, Yogyakarta

Halim dan Husnul, 2012, Perilaku Keorganisasian dan Kepersonalian, BPFE, Yogyakarta

Hasibuan,Malayu, 2007, Manajemen Sumber Daya Manusia, Edisi Revisi, Bumi Aksara, Jakarta

Husnan dan Heidjrahman, 1999, Manajemen Sumber Daya Manusia dan Personalia, BGFE, Yogyakarta

Instruksi Presiden Nomor 2 tahun 1999 tentang Pemisahan Polri dri TNI/ABRI,Jakarta

Kep Menpan No 04/199 Menjelaskan Tentang Budaya Kerja, Jakarta

Kepmenpan Nomor

25/KEP/M.PAN/04/2002, budaya kerja, Jakarta

Mas'ud, 2009, Perilaku dan Budaya Organisasi, Erlangga, Jakarta

Mahmud, 2011, Keroganisasian dan SDM, Rineka Cipta, Jakarta

Mangkunegara, Anwar Prabu, 2011. Manajemen Sumber Daya Manusia. Edisi Revisi, Bandung: PT Ramaja Rosdakarya.

Marihot. Effendi, 2012, Manajemen Perusahaan, Pustaka Setia, Jakarta

Melky.S, 2004, Perilaku SDM di Dalam Organisasi Bisnis, Alfabeta, Bandung
Moenir, 2010, Perilaku Keorganisasian, Rineka Cipta, Jakarta

Maimun,2009, Manajemen SDM, Ghalia Indonesia, Jakarta

Mulyanto, 2013, Manajemen Bisnis dan Keorganisasian, Bumi Aksara, Jakarta

Nataly, 2010, Perilaku Organisasi dan Kepersonalian, Rineka Cipta, Jakarta

Nasution, 2010, Manajemen SDM, Graha Ilmu, Yogyakarta

Ndraha. Taliziduhu, 2013, Budaya Organisasi, Rineka Cipta, Jakarta

Nawawi, 2011, Budaya Kerja, BPFE, Yogyakarta

Nitisemito, 2006, Manajemen Personalia dan SDM, Ghalia Indonesia, Jakarta

Peraturan Kepolisian Negara Republik Indonesia Nomor 8 Tahun 2018 tentang tugas pokok Kepolisian Negara Republik Indonesia, Jakarta

Rivai. Vencent, 2012, Budaya Kerja, Rineka Cipta, Jakarta

Roni Setiawan, 2014, Pengaruh Hukuman, Budaya kerja dan Penghargaan terhadap Kinerja Pegawai Pada Badan Pemberdayaan Masyarakat dan Pemerintah Desa (BPMPD) Kabupaten Banjar, Unlam, Banjarmasin

Sardiman, 2002, Pengeloaan Budaya Kerja dan Organisasi, Gramedia, Jakarta

Sularso, 2004, Perilaku Keorganisasian, Liberty, Jakarta

Soemanto, 2008, Psikologi Bisnis, Gramedia, Jakarta

Sofo. Vincenzo, 2013, Perilaku Organisasi, Pustaka Setia, Jakarta

Sekaran, Uma, 2009, Reseach Method For Business (Skill Building, Approach), Third Edition, John Weiley and Sans Inc, America

Sofyandi, 2009, Manajemen SDM, Rineka Cipta, Jakarta

Suhardjito, 2009, Manajamen, Remaja Prees, Jakarta

Sugiyono, 2009, Metode Penelitian Admisnitrasi, Alfabeta, Bandung

Sulaksono, 2012, Budaya Kerja (Implementasi Keorganisasi), 
Balai Pustaka, Jakarta

Schuler dan Jackson, 2001, Managemen Education. Journal of Educations Research Vol.10, No.1. pp,90-98.

Siagian. Sondang P, 2013, Manajemen SDM dan Personalia, BPFE, Yogyakarta

Swansburg, 2009, Motivation and Performance in Industrial Selling: Present Knowledge and Needed Research. Journal of Management, 14 (May), pp. 156-168

Srimulyo, 2009, Ilmu Manajemen Bisnis, Bumi Aksara, Jakarta

Sulistyo, 2009, Ekonometrik, Buku Dua, Lembaga Penerbit Fakultas Ekonomi Universitas Indonesia, Jakarta
Testiana, 2012, Budaya Keorganisasian, Balai Pustaka, Jakarta

Tap MPR Nomor VI/2000 Tentang Pemisahan TNI dan Polri, Tap MPR Nomor VII/2000 Tentang Peran TNI dan Peran Polri, Jakarta Undang-Undang Nomor 2 Tahun 2002 tentang Polri, dan Kebijakan Strategis Kapolri 2002-2004. Jakarta

Wibowo 2011, Manajemen Pengelolaan SDM, Pusaka Tjaya, Surabaya

Yusran Akhmad, 2015, Pengaruh Budaya Kerja, Penghargaan dan Hukuman terhadap kinerja pegawai pada Pemerintah Kota Banjarbaru, Unlam Banjarmasin 